\title{
Originals
}

\section{Plasma Prolactin in Juvenile Diabetics}

\author{
24-h Studies with Somatostatin \\ K. F. Hanssen ${ }^{1}$, S. E. Christensen ${ }^{2}$, Aa. P. Hansen ${ }^{2}$, K. Lundbæk ${ }^{2}$, P. A. Torjesen ${ }^{1}$, and J. Weeke \\ ${ }^{1}$ Medical Department B and Hormone Laboratory, Aker Hospital, Oslo, Norway \\ and ${ }^{2}$ Second University Clinic of Internal Medicine, Kommunehospitalet, Aarhus, Denmark
}

Summary. In normal subjects during 24-hours saline infusion, plasma prolactin showed a number of small rises during day and night. The mean night-time level was significantly higher than the day-time level $(8.2$ $\pm 0.6 \mathrm{ng} / \mathrm{ml}$ as against $4.7 \pm 0.5 \mathrm{ng} / \mathrm{ml}$ ). In 12 insulindependent diabetics the $24 \mathrm{~h}$ plasma prolactin pattern was identical to that found in normals. Somatostatin infusion $(4 \mathrm{mg} / 24 \mathrm{~h}$ in normals; $2-6 \mathrm{mg} / 24 \mathrm{~h}$ in diabetics) had no effect on the $24 \mathrm{~h}$ plasma prolactin pattern in either normals or in diabetics.

Key words: Juvenile diabetics, plasma prolactin, somatostatin.

Prolactin has been considered a diabetogenic hormone, because injection into dogs results in hyperglycaemia [1] and because endogenous hyperprolactinaemia in humans is accompanied by glucose intolerance in spite of hyperinsulinaemia [2].

An early study suggested that plasma prolactin was elevated in some diabetic patients, especially those without or with only mild retinopathy [3].

Somatostatin inhibits the in vitro secretion of prolactin from anterior pituitary cells in monolayer cultures $[4,5]$. However, the basal prolactin secretion and the secretion induced by insulin, arginine and TRH in normal man has not been shown to be inhibited by somatostatin [6-9].

The present study was performed to determine the diurnal plasma prolactin level in normals and juvenile diabetics during 'daily life' conditions, and to investigate the effect of somatostatin infusion on these levels.

\section{Material and Methods}

The control subjects were four healthy, young, non-obese, male medical students. The diabetic group consisted of 12 young, nonobese, male subjects with juvenile type diabetes. They received insulin in one or two daily doses during the experiment. None of them had signs or symptoms of diabetic angiopathy. Full details of the subjects studied and experimental procedure are given in an earlier paper [10].

On the day of experiment, indwelling catheters were inserted bilaterally in antecubital veins for blood sampling and infusion of saline or somatostatin. The experiment started at $0800 \mathrm{~h}$. Blood was drawn hourly during the following 51 hours. Saline $(0.154 \mathrm{~mol} / 1)(500 \mathrm{ml})$ was infused during the first 24 hours. Cyclic somatostatin (dissolved in $500 \mathrm{ml}$ saline) was infused during the following 24 hours. During the last three hours no infusion was given. Control subjects received a total dose of $4 \mathrm{mg}$ somatostatin. Four diabetics received $2 \mathrm{mg}$ somatostatin, four received $4 \mathrm{mg}$ and four $6 \mathrm{mg}$. During the study the subjects were confined to bed, they were allowed to sleep only at night. None of the subjects received any medication except insulin. They all received a standard diet. Plasma glucose was measured by a glucose oxidase method, and plasma prolactin by radioimmunoassay [11].

Paired Student's t-test were used for statistical analysis of differences between saline and somatostatin experiments. Student's $\mathrm{t}$-test was used for determination of differences between normal subjects and diabetics.

\section{Results}

Figure 1 shows the mean plasma prolactin concentration in the four normal subjects and the 12 juvenile diabetics during the 24 hour saline infusion period (upper two curves) and during the 24 hour somatostatin infusion, followed by the three hour control period (lower two curves). In both normals and diabetics during saline infusion plasma prolactin showed a number of small rises during the day and night. The night-time concentration (Table 1) was significantly higher than the day-time concentration in the normals $(p<0.05)$ and also in the diabetics 


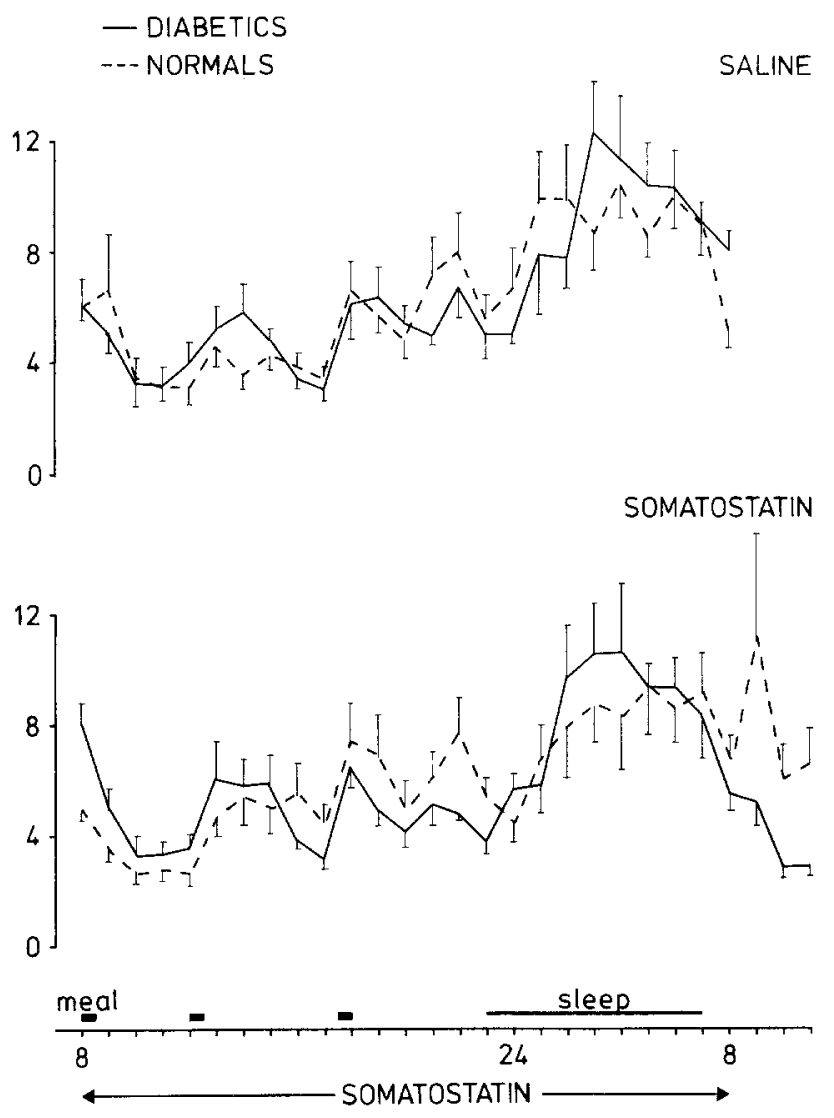

Fig. 1. Plasma prolactin concentration (mean \pm SEM) during a $24 \mathrm{~h}$ period in 4 normal male subjects and 12 male juvenile diabetics. A $24 \mathrm{~h}$ period of saline infusion was followed immediately by $24 \mathrm{~h}$ of somatostatin infusion. During the following three hours no somatostatin or food was given

$(p<0.02)$. There were no differences in the mean 24 $\mathrm{h}$ plasma prolactin concentration between normals and diabetics during saline infusion $(6.3 \pm 0.5 \mathrm{ng} / \mathrm{ml}$ as against $6.5 \pm 0.7 \mathrm{ng} / \mathrm{ml}$ ).

The same diurnal patterns in plasma prolactin were observed during somatostatin infusion in both normals and diabetics, with minor peaks during day and night and higher concentrations during the night than during the day in both diabetics $(\mathrm{p}<0.001)$ and normals. The mean $24 \mathrm{~h}$ plasma prolactin concentrations during somatostatin infusion were the same in normals and diabetics $(6.1 \pm 0.3 \mathrm{ng} / \mathrm{ml}$ as against 6.0 $\pm 0.7 \mathrm{ng} / \mathrm{ml})$. There was no dose response relationship. Cessation of somatostatin infusion did not induce any significant rebound secretion of prolactin in diabetics or normals.

\section{Discussion}

The present study shows that the $24 \mathrm{~h}$ level of plasma prolactin in diabetic patients is similar to that of nondiabetics and is unaffected by somatostatin.

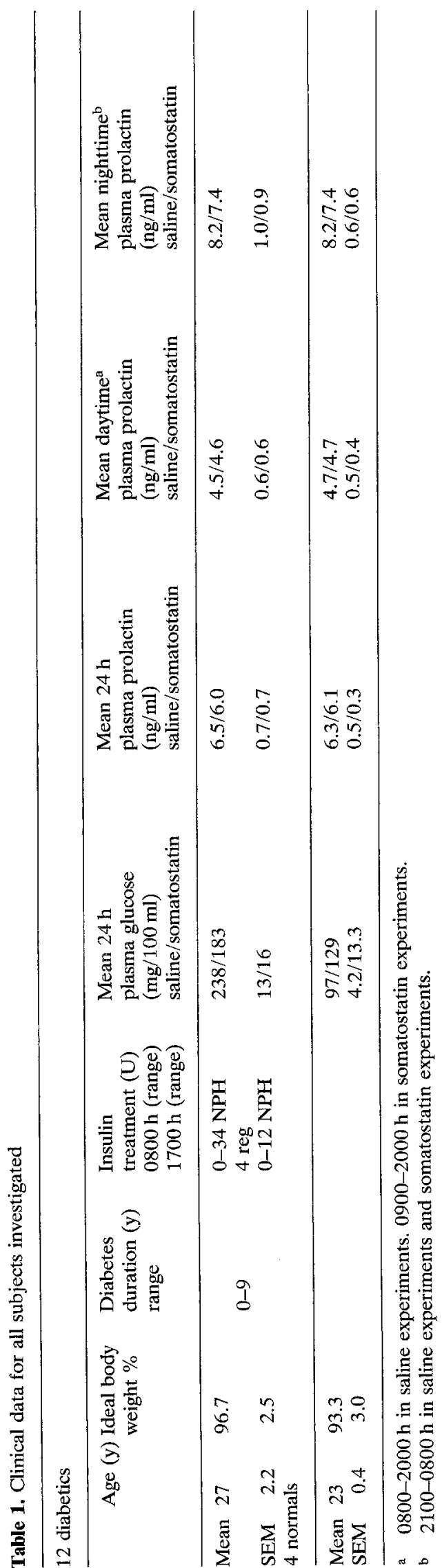


The $24 \mathrm{~h}$ pattern observed is similar to that shown earlier in normal man [12, 13].

There are few reports about prolactin in diabetes mellitus. Plasma prolactin concentrations have been found to be increased in single samples from a small series of diabetic patients without or with only simple retinopathy compared to normal concentrations in diabetics with severe retinopathy [3]. This finding, however, was not confirmed in a larger study, where samples were obtained every 4 th hour during a $24 \mathrm{~h}$ period [14] and in another study measuring basal and TRH stimulated prolactin concentrations [15]. In both studies plasma prolactin was found within normal limits in patients with and without retinopathy.

Diabetic ketoacidosis is accompanied by increased plasma prolactin concentrations, which decreases during insulin treatment [11].

It can be concluded that plasma prolactin levels are normal in diabetic patients without retinopathy in ordinary metabolic control conditions. This is in contrast to the elevated plasma growth hormone levels found in diabetic patients $[16,17]$.

Somatostatin infusion had no effect on plasma prolactin when studied during a $24 \mathrm{~h}$ period of 'normal life' in diabetics and in normals. This finding is in accordance with short-term infusion experiments in normal man where the basal secretion of prolactin and the secretion induced by insulin, arginine and TRH are not inhibited by somatostatin [6-9].

\section{References}

1. Rathgeb, I., Winkler, B., Steele, R., Altszuler, N.: Effect of ovine prolactin administration on glucose metabolism and plasma insulin levels in the dog. Endocrinology 88, 718-722 (1971)

2. Landgraf, R., Landgraf-Leurs, M. M. C., Weissman, A., Hörl, R., von Werder, K., Scriba, P. C.: Prolactin: A diabetogenic hormone. Diabetologia 13, 99-104 (1977)

3. Hunter, P. R., Anderson, J., Lunn, T. A., Horrobin, D. F., Boyns, A. R., Cole, E. N.: Diabetic retinopathy and prolactin. Lancet 1974 I, 1237

4. Grant, N. H., Sarantakis, D., Yardley, J. P.: Action of growth hormone release inhibitory hormone on prolactin release in rat pituitary cell cultures. J. Endocrinol. 61, 166-164 (1974)
5. Vale, W., Rivier, C., Brazeau, P., Guillemin, R.: Effects of somatostatin on the secretion of thyrotropin and prolactin. Endocrinology 95, 968-977 (1974)

6. Hall, R., Besser, G. M., Schally, A. V., Coy, D. H., Evered, D., Goldie, D. J., Kastin, A. N., McNeilly, A. S., Mortimer, C. H., Phenekos, C., Tunbridge, W. M. G., Weightman, D.: Action of growth-hormone-release inhibitory hormone in healthy men and in acromegaly. Lancet 1973 II, 581-584

7. Copinschi, G., Virasoro, E., Vanhaelst, L., Leclercq, R., Golstein, J., L'Hermite, M.: Specific inhibition by somatostatin of growth hormone release after hypoglycaemia in normal man. Clin. Endocrinol. (Oxf.) 3, 441-445 (1974)

8. Siler, T.M., VandenBerg G., Yen, S. S.C.: Inhibition of growth hormone release in humans by somatostatin. Clin. Endocrinol. Metab. 37, 632-634 (1973)

9. Carr, D., Gomez-Pan, A., Weightman, D. R., Roy, V. C. M., Hall, R., Besser, G. M., Thorner, M. O., McNeilly, A. S., Schally, A. V., Kastin, A. J., Coy, D. H.: Growth hormone release inhibiting hormone: Actions on thyrotrophin and prolactin secretion after thyrotrophin-releasing hormone. Br. Med. J. 1975 I, 67-69

10. Christensen, S. E., Hansen, Aa. P., Weeke, J., Lundbæk, K.: 24-hour studies of the effects of somatostatin on the levels of plasma growth hormone, glucagon, and glucose in normal subjects and juvenile diabetics. Diabetes 27, 300-307 (1978)

11. Hanssen, K.F., Torjesen, P. A.: Increased serum prolactin in diabetic ketoacidosis, correlation between serum sodium and serum prolactin concentration. Acta Endocrinol. (Kbh.) 85, 372-378 (1977)

12. Sassin, J. F., Frantz, A. G., Weitzman, E. D., Kapen, S.: Human prolactin: 24-hour pattern with increased release during sleep. Science 177, 1205-1207 (1972)

13. Parker, D. C., Rossmann, L. G., Vanderlaan, E. F.: Sleepreleated, nyctohemeral and briefly episodic variation in human plasma prolactin concentrations. J. Clin. Endocrinol. Metab. 36, 1119-1124 (1973)

14. Harter, M., Balarac, N., Pourcher, Ph., Koslowski, J. M., Krebs, B., Ramaioli, A.: Diabetic retinopathy and prolactin. Lancet 1976 II, 961-962

15. Frøland, A., Hagen, C., Lauritzen, E.: Diabetic retinopathy and prolactin. Lancet 1977 I, 45

16. Hansen, Aa. P.: Serum growth hormone patterns in juvenile diabetes. Dan. Med. Bull. 19 (Suppl. 1), 1-32 (1972)

17. Hanssen, K. F.: Urinary growth hormone. Oslo: Thesis, Universitetsforlaget 1975

Received: April 19, 1978,

and in revised form: June 15, 1978

Aa. Prange Hansen

Second University Clinic

of Internal Medicine

Kommunehospitalet

DK-8000 Aarhus

Denmark 